\title{
TWO PERSPECTIVES ON THE ISSUE OF PRUDENCE (PRUDENTIA): THOMAS AQUINAS AND WILLIAM OF OCKHAM ${ }^{1}$
}

\author{
Rastislav Nemec - Andrea Blaščíková
}

DOI: 10.17846/CL.2021.14.2.51-60

\begin{abstract}
NEMEC, Rastislav - BLAŠČÍKOVÁ, Andrea. Two Perspectives on the Issue of Prudence (Prudentia): Thomas Aquinas and William of Ockham. The text focuses on a comparison of the concept of prudence from the points of view of Thomas Aquinas and William of Ockham, detailing four various insights into the core of prudence. The first concerns the position of the virtue of prudence within the framework of ethics; the second deals with the role of will and the intellect in regard to virtue; the third describes the principles of prudence; and the fourth is dedicated to relations between an exterior and interior act of virtue. On the basis of the comparison, we discover that the understanding of prudence has changed radically along with the transformation of the relations among reason, will and natural inclinations. While prudence, according to Aquinas, illuminates us the ways to properly pursue the good of our natural inclinations, Ockham does not associate prudence and virtue with the idea of inclination at all. This change also had an impact on the perception of an exterior act of virtue. An interior act is crucial for both authors, but while Aquinas sees an exterior act as the apex of prudence, Ockham is not convinced about the importance of reaching it. In the case of Ockham's ethical theory, there is a distinct shift from the ethics of virtue towards the incoming modern formalism and individualism.
\end{abstract}

Keywords: prudence (prudentia), virtue, Thomas Aquinas, William of Ockham

\section{Introduction}

The aim of the paper is to compare the concepts of prudence (prudentia) in two authors of the medieval world - Thomas Aquinas and William Ockham. Since prudence is a part of complex topics related to human moral conduct in both authors, to the extent that they shed light on the nature of prudence, these contexts will also be the subject of comparison. For both authors, we will gradually comment on four points that are essential to their understanding of prudence: a) the place of prudence as a virtue in their ethical system following Aristotle as the reference point; b) the role of will and intellect in virtue and especially in the virtue of prudence; (c) the principles of prudence; (d) the relationship between exterior and interior act of the virtue. We will first (1) examine these points of comparison with Thomas Aquinas. Since the link between Thomas Aquinas and William Ockham is represented by John Duns Scotus, in the next part (2) we will very briefly outline Scotus's way of thinking about virtue. In the third step (3), we will focus on

The paper was supported by the Scientific Grant Agency of the Ministry of Education, Science, Research and Sport of the Slovak Republic and the Slovak Academy of Sciences (VEGA 1/0637/20 Impulses from Medieval Philosophy in Today's Thought) and the Slovak Research Development Agency (APVV-17-0158 Perspectives religiosity development in Slovakia). 
the concept of prudence in William of Ockham. In conclusion (4) we depict and summarize the similarities and differences between the two authors.

\section{Thomas Aquinas on prudence}

Thomas Aquinas (1225 - 1274) was significantly influenced by Aristotle in his understanding of ethics as well as the virtue of prudence (prudentia). However, this does not mean that in some aspects he did not bring innovations or use elements of thinking of other authors (Volek $2011,11)$. In analyzing his concept of prudence, we rely primarily on his work Summa theologiae (hereinafter STh).

Prudence has a special position in Thomas's systematization of virtues. With regard to its essence, it belongs to the intellectual virtues, but with regard to the matter to which it relates, it belongs to the moral virtues. Thomas also places it among the principal or cardinal virtues. Its place is in the practical reason, which directs the known truth to operation. Tomas defines it as a recta ratio agibilium, which means "a correct understanding of what can be caused by action" (Němec 2008, 144).

But what can be caused by our actions? We make something and we do something by our acts. Making is an action by which we change the external world, for example, to build, to saw, and so forth. Doing is an action abiding in the agent, e. g. to understand, to will, and the like. The virtue that improves the making is called art or technical skill (ars). The result is a good work, which does not necessarily mean the good character of the acting person. An artist does not have to be a moral person, although he can be a good artist. The virtue that causes the good character of its owner is called prudence (Machula 2020, 11).

A good character can be considered as the interior good of man. Prudence is a virtue that advises a man how to become a good man and thus achieve beatitude. All our acts are motivated by the desire to attain beatitude (STh I-II, q. 1, a. 6). All people agree in this natural desire, although they do not agree in what the beatitude of man is. According to Thomas, beatitude is an object of the will, but it lies in the activity of the intellect, especially speculative rather than practical. According to Thomas, the intellect is the best human ability (optima potentia). The best object of the intellect is the highest good, the divine good. The will is attracted by the highest good, but it is the intellect that apprehends and grasps the good. The will thus achieves its object as apprehended by the intellect. Only when the intellect apprehends the essence of the highest good, the will attains final rest and delight (enjoyment). In the conditions of this life, the apprehension of the highest good essence is only partial. Therefore, in this life a man can attain only an imperfect beatitude. The imperfect beatitude also lies primarily in vision, i. e. in the activity of the speculative intellect. But secondarily also in the activity of the practical intellect, directing human actions and passions.

The activity of the practical intellect, since it concerns human acts and human good in the present life, is necessarily connected with the activity of the will. Human life "consists of many acts of the will together with the external acts arising from them" (Gallagher 2002, 78). ${ }^{2}$ Among the individual objects (acts), the will chooses those that promise to achieve better the intended end. Thomas understands these chosen subjects as means to the end (ea quae sunt ad finem). In order for the will to be correct, it is required that it chooses the subjects on the basis of the judgement

2 The emphasis on the intentionality of the will and the doer inner way of thinking, which precedes exterior acts, was placed in ethics in the 12th century by Peter Abelard (Vašek 2013, 487). 
of reason. Recognizing the proportionality of an act in relation to the end is a task of the practical reason.

Prudence improves the intellectual ability to correctly specify the proportion of the act in relation to the end. According to Thomas, a man would not be able to find appropriate ways to his beatitude if he were not disposed to it both on the side of appetite and reason. Prudence presupposes as its prerequisite the right appetite and the rational disposition containing the first principles of human acts (synderesis).

A prerequisite for prudence on the side of appetite is an inclination to the appropriate end. This inclination is given both by nature and by moral virtue. "For example, justice makes it [appetite] incline towards the good that is equality in things that are part of our shared life, while temperateness makes it incline towards the good of restraining oneself from the objects of sensual desire, and so on with each virtue" (De virtutibus, q. 1, a. 6). However, the natural inclination for good of virtue is only the beginning of the virtue (inchoatio virtutis), not the perfect virtue. "For the stronger this inclination is, the more perilous may it prove to be, unless it be accompanied by right reason, which rectifies the choice of fitting means towards the due end" (STh I-II, q. 58, a. 4 to 3). What it means to be just, temperate, brave in particular situations has many forms. Prudence specifies what the end is in the particular situation. However, it does not belong to prudence to establish the end to moral virtues, but only to regulate the means to the end.

Prudence is thus preceded, in terms of appetite, by a natural inclination towards the end, the human good. On the part of reason, it is preceded by the natural knowledge that the human good to which moral virtues are directed is to be in accord with reason (secundum rationem esse). Thus, man naturally knows that as a person he develops himself when he chooses in accord with reason. He knows that he must act in accord with that his reason recognizes to be right. He knows that "good is to be done and pursued, and evil is to be avoided" (STh I-II, q. 94, a. 2). This guidance is naturally known to him as the habit of practical reason, called synderesis. Thomas considers it to be the second prerequisite for prudence.

Knowing the end of appetitive power means knowing the basic principle of action. This principle will develop into the so-called natural law, when a man rationally recognizes the individual goods to which his nature inclines. Human nature tends towards three groups of goods: the preservation of one's own existence, the good of sensitive knowledge and sensitive appetite, and the good of rational knowledge and rational appetite. The good of social life also belongs to this third inclination (Chabada - Szapuová 2017, 699-700). The most universal principles are based on the knowledge of these inclinations, such as: Acting in such a way that one ensures his own persistence and avoids what contradicts the preservation of being. Educate offspring. Avoid ignorance. Not to offend those among whom one has to live and other such things (STh I-II, q. 94, a. 2).

However, knowing inclinations and the goods of human nature as principles of action does not mean achieving the end of moral virtue. It belongs to the ruling of prudence to decide in what manner and by what means a man shall obtain the mean of reason in his acts. This is achieved only when reason correctly determines how and through what (qualiter et per quae) one should act in order to be directed to the end.

This operation is performed by prudence as a kind of practical syllogism. "Practical syllogism [...] resembles the speculative in its structure, but differs with respect to its connection with desire and action" (Osborne 2014, 62). According to M. Rhonheimer's explanation, the first premise of practical syllogism captures the good of human appetite as what is to be realized as an end. For example: "I want to stay alive / It is good (for me) to keep myself alive." The second premise is a statement based on experience, a statement about a practically relevant state of affairs. This statement is a speculative judgment, or theoretical judgment or a sense perception. For example: "Taking in nourishment keeps me alive." The conclusion specifies how and through what the goal 
is achieved, i. e. the act to be performed: "I want to take in nourishment / It is good (for me) to take in nourishment" (Rhonheimer 2011, 117-118).

Practical syllogism corresponds to two operations of rationality: the counsel and the judgment. To counsel (consilium), by its definition, is an intellectual search for an action by which human good, and thus the end of moral virtue, could be achieved in a particular situation. The main criterion of a right counsel is the end, but in the search for appropriate means to the end, other principles also help prudence, namely principles adopted in sense experience or principles universally known through speculative or practical science. The classification also includes consideration of the numerous conditions and circumstances of the act. Judgment (iudicium) is the conclusion of syllogism, and thus the final statement of what is to be done.

For Thomas, however, the competence of reason does not end with the judgment. A man can know what to do and still not perform the act. He may be deterred from committing an act by an obstacle on the part of his sense appetite, that is, by an inordinate desire, as a result of which he lacks the permanence and determination to carry the judgement out. This withdrawal from the execution of an act is consummated (consummator) in the reason, "which is deceived in rejecting what before it had rightly accepted" (STh II-II, q. 53, a. 5). In order not to fail to apply the judgment to the acts, the reason must be perfected accordingly. This operational perfection of the practical reason, which is at the same time the main act of prudence, is called a command (praeceptum, imperium).

According to Thomas, the command is not an act of will, but of reason. The will moves the individual powers to perform an act (usus), but reason directs this motion. The will is the root of liberty and action, but reason is its cause (STh I-II, q. 17, a. 1). Therefore, the command to perform an act belongs to reason, presupposing an act of the will. Without this operation, the end of the practical reason - human act - would not be achieved.

As a result of the cooperation of the intellectual and appetitive power, human action has two components: interior and exterior. The interior one consists of: a) the initial apprehension of the good to which a man inclines, and the intention to achieve that good; b) the counsel and the judgment on what it means to achieve the intended good in particular; c) the choice followed by the command to perform the act. An exterior act is an execution of a command, using the will. Just as virtue is the result of the cooperation of will and reason, so the act of virtue is the result of the dynamics of will and reason in the execution of the act. Immanence, which characterizes the activity of prudence thus "results necessarily in a sort of emanation, and spilling over into interactions with the world, a growth of the individual in its virtue which manifests itself in its external actions" (Kremple 2017, 570).

\section{Ockham and his starting points}

The issue of prudence is quite complex in Ockham (1285 - 1347). In our analyses, we will rely primarily on two of his works: Quaestiones variae (OTh VIII) and Ordinatio (OTh I).

Ockham was influenced by the teachings of Duns Scotus (1266 - 1308) in this subject. In short (also for the sake of chronological accuracy) we will indicate Scotus' understanding of prudence and virtue in general. Scotus responds to Aquinas directly, while Ockham responds only to certain passages. Therefore, by his teaching we will better connect this topic and better explain the background that forms the centre of Ockham's teaching on prudence.

Scotus rejects the position that virtues are based on good that are indicated by natural inclinations shared with non-rational creatures. For Scotus, the source and principle of virtue is the will, which is free. The will is free, which means, on the one hand, that it has a power 
over the acts one intends to perform. And on the other hand, it is free if nothing impedes it from choosing: to decide whether to act (to act or not to act) and what to act (whether or not to do). It is free even because it can decide against what the intellectual judgment offers (which Aquinas did not accept) and it can even decide for evil. Therefore, for Scotus, a free act results from free will - only if the will is free, can its acts also be free, and only then they are virtuous. According to him, virtues differ only in what their end is and what the will is decided for. The end of speculative knowledge is theoretical truth; the end of practical knowledge is truth related to practical action. We use speculative and practical reason in both cases - these are the basic differences compared to Aquinas (Osborne 2014, 82-83). How does he understand prudence in this way?

According to Aristotle's way of thinking in the Nicomachean Ethics 6, 3 1139b15, which states that prudence refers to a specific action, Scotus in some of his works, but especially in Lectura in Librum Primum Sententiarum (Prol. 4, q. 1-2, 174) distinguishes three instances of practical reason: the first are the general principles, the second is moral science, and the third is prudence acquired from experience. The first instance is represented by the principles that the human mind recognizes by itself. These are principles that have a theoretical basis and are indisputable (e. g. honestum vivendum est). Such basic moral principles are evident to the intellect: "God is to be loved above all things" and many more. The other two are problematic: prudence (prudentia) and moral science (scientia moralis). Moral science is a general source of practical action because it contains the principles and rules by which action must be taken. They are learned. Prudence is not so universal and it is much more "concrete". It directly encourages action, which moral science does only in general. Moral science represents knowledge that we have learned or that we have come to on the basis of rational reasoning. These alone are not enough to determine what exactly we need to do. It is practical knowledge only secondarily, as it comes to action only on the basis of discursive considerations. Therefore, we could, to some extent, label moral science as speculative knowledge. Moral science is universal in this sense, but a specific moral act is particular. And therefore the third instance is important: prudence (prudentia) as a practical habit that directly controls the practical realm, it is the immediate and "closest disposition to action that is connected with the correct knowledge" (Scotus 2005, 183).

Scotus hereby suggests, with the intentions of Aquinas, that moral science alone is not enough. It is not enough just to know the principles of action in order for man to be prudent. It is not enough even to make decisions according to these principles. Prudence is related to specific practical actions, the first principle of which is will (Chabada 2008, 244). Therefore, if in this case there is no minimum act of will which has some practical end, there can be no virtue of prudence. On the contrary, if there is an end that is not practical, there is only a theoretical consideration of the principles of action. But prudence requires having a practical act as its end. And virtue is a practical act (will). At this point, Scotus will be an inspiration to Ockham.

But what is the difference compared to Aquinas? Scotus claims that there is only one prudentia, but it should be understood as a genus. This means that it refers to different cases and different actions as one common prudence, although it has different lesser species, which Ockham agrees with. Scotus notes that someone may lack the opportunity to gain prudence in one type of activity, even though they have it in another sphere, in different actions or considerations. If he does not have it in one sphere (e. g. in moderation), he can have it in another (courage to battle). Just like when he has one technical skill and has no other. Ockham, unlike Scott, will argue that there are exactly as many kinds of prudence as there are habits of practical knowledge. As there are many habits of practical knowledge, there will be so many kinds of prudence. 


\section{Ockham on prudence}

In this, Ockham follows Scott in his critique of Aquinas. In particular, he agrees with Scotus's distinction that moral science is universal and that the habitus of prudence refers to a specific act (habitus prudentiae sunt particulares). He even adds the fact that universal principles are not only those which the reason recognizes a priori, but also those which the reason derives from experience (Ockham 2016, 110). Unlike Thomas, Ockham does not think that interest in specifics is a characteristic privilege of practical action. The typical opinion of the doctor invincibilis is that the premises in syllogism can be speculative even if they are specifics. According to him, universality is not only the privilege of the speculative knowledge, but also the practical one.

In his work De connexione virtutum, Ockham characterizes prudence in four ways: first, he defines it as a moral science (scientia moralis), in a broader and narrower sense. In a broader sense, it is a combination of speculative and practical knowledge. Thus, moral science in this sense represents considerations of action in general, and Ockham matches it with various philosophical and ethical writings (e. g. Nicomachean Ethics, or the Gospel). Moral science in the narrower sense is understood by practical knowledge directly in a situation where we can do something (Ockham 1967, I Prol. Q. XII Resp ad Hen. 15-20). In this case, we can do something, as long as the situation allows and as long as the situation requires. In the case of scientia moralis, therefore, it is not a matter of metaethics and a reflection on circumstances and appropriate means as in Aquinas, but of practical knowledge, although this more narrowly defined part of moral science is nevertheless governed by universal knowledge of moral principles. Moral science is thus focused on practice, but it does not determine how to act in an individual case. Take, for example, the moral principle: "Omni benefactori est benefaciendum". We can grasp this sentence in different ways. However, it is not for moral science to determine how to understand it. This can be done by prudence, in which he distinguishes between two meanings. By first meaning, he grasps prudence as the knowledge that immediately leads us to action (as Aristotle also understood it). But unlike Aristotle, Ockham associates it more with the experience from which prudence draws on. Although Ockham says that prudence is the "evident knowledge" (notitia evidens), he adds that it is also acquired through experience (mediante experientia), which is governed by a contingent proposition. What does it mean?

Ockham claims that experience (experientia) offers us equally proven evidence and verified knowledge. He even sees in it a possible source of new principles of action, which Aquinas rejected. Although moral science and prudence in principle also lead to practice, Ockham is well aware of the important function of practical experience. In many cases, as he claimed, personal experience is needed to be able to put the general principles into practice at all. Therefore, the general knowledge acquired through the study of morality is not always sufficient. The practical experience by which we acquire the principle, although it is less universal, gives us greater certainty in action - which we do not gain by general knowledge. Practically experienced people (experts) act more confidently, although they do not have to show any high abstract thinking and do not know how to perceive causal connections. Thinking in causal contexts from principles to consequences is rather marked by the knowledge of specialists (artifices).

Thus, there is a kind of tension in Ockham himself as to what place belongs to moral science and what place belongs to rationality. From a reflection on this problem, we could say the following: from the point of view of science and in the perspective of knowledge, Ockham puts moral science higher than prudentia. Knowledge of principles also belongs to scientia moralis. However, moral science, which is purely scientific, lacks the certainty of action which belongs to prudence on the basis of the experience that people achieved. If we look at this relation from the perspective of certainty, then Ockham values prudence above moral science. 
The contingency of the world, on the one hand, makes it always questionable whether our actions will be "morally successful" because of the changing conditions of the world. Ockham as we will see below - does not even depend on his external feasibility. It takes into account the possibility that the intention may not be carried out externally. Sometimes "success does not depend on the doer" (Niederberger 2013, 128). Sometimes it is determined by both the circumstances and the bodily constitution of the doer. Therefore, it is not relevant if the act succeeded when we should decide about goodness of the doer and his intentions. Otherwise would circumstances determine whether the act is moral or not.

Ockham approaches the last kind of prudence as something that is different for individual virtues - and it is in this difference that specific kinds of prudence are characterized. This last type of prudence Ockham relates directly to the actual act. Just as prudence in the previous meaning was based on experience, and experience can only be learned if experience is repeated (habitus arises), or if we discover something unknown by our findings, this kind of prudence refers to current action and decision-making and does not take this repetition into consideration. In general, Ockham emphasizes that both the ethical principles (of moral science) and all the circumstances of the act (will, reason, chosen end) must be specified for a specific situation - that is, they must be act(ualized) by the current act - action. Unlike Thomas Aquinas, he understands virtue primarily as an act of will. In this case, prudence cannot be referred as a habit. It is at this point that Ockham comes into conflict with the Aristotelian teaching of virtue as habitus custom, habit, repetition, as in the case of the relationship between moral science and reason and the conflict between actual and habitual knowledge. In what relationship could the two instances work together?

It can be said that Ockham establishes two basic versions: either the "pure" application of the principles contained in moral science in a particular act is conceivable, which would mean that our action would "fit" into a series of similar actions in similar situations, but a man would not think or choose - which are de facto circumstances of moral conduct. In this type of action, it immediately occurs to us that it is not at all certain whether we would call such an action proper and moral at all. If it lacks the aspect of knowledge and voluntariness, we cannot speak of virtuous conduct (ex libertate) (nullus virtuose agit nisi scienter agat et ex libertate) (Ockham 2016, 135). Applying the principles of moral conduct without rational consideration would not be a virtuous act.

At this point, he gives the example of a man who acts according to how he has acted and what he has known in the past. Ockham describes him as "fatuus virtuosus" - and Rega Wood sees in this term fatuus a reference to some mental disorder (Wood 1997, 238). For example, an enraged man does not know about himself and he does not even know what he is doing. In the past, however, he has learned to do something that seems reasonable and now he repeats this action. Thus, it may give other people the impression that what he is doing is morally praiseworthy, even though he is actually doing something he learned as a child. As a child, he was aware of some moral principles, and he now - with a mental disorder - implements them as a habit. Ockham refuses to call such a person sensible and virtuous and his action as right.

The second option, in the case of an aporia of the relationship between habitual and current knowledge, would be "actualization" of this habitual knowledge. The acting person is therefore aware of himself as the doer and decides on some end of the action. This second option allows us, in some kind of intuition, to emphasize what is morally correct and in a given situation, to look intuitively for a way that the general norm is not completely denied and at the same time not reduced precisely because of this particular situation. According to Ockham, prudence is sufficiently justified only in this case. It actively considers and sensitively and perceptively searches for the most appropriate way to execute something that the will has willed to be done. The choice, 
therefore, is not just to find the right means to an end. The choice is an act of will, and therefore, if it is free, it is already good in itself. According to Ockham, the search for means is related to their external realization, which may not succeed, and yet such an act is good in nature. He sees the core of such an act in the intention (intentio) of the doer.

Emphasizing the intention in moral action, Ockham - like Aquinas - outlines his theory of virtue in relation to exterior and interior acts. However, this version of Ockham is radically different from the theory of Aquinas and Scotus. Virtues are often used to refer to something that happens outside. An act which is performed and it is said that it is virtuous. However, Ockham argues that only an interior act of will, accompanied by a judgment of reason, can be virtuous. This interior act of will is the first stage of the action. The human will does not yet enter into the realm of the contingent circumstances of this world as exterior acts, which often divert these circumstances from the end. And above all, it is in the power of the will.

Ockham argues that any action is virtuous only because of prudence (nihil actus virtuosus sine prudentia). But he means that it is a part of an interior act by which the will realizes its intention. Unlike Aquinas, it is not at all paramount whether it gets to an exterior act at all.

\section{Conclusion}

For both Aquinas and Ockham, prudence is related to the choice of a particular act. According to both, this choice is free, but they understand freedom of choice differently. In Thomas, the root of freedom is the will, but the cause is reason. Will is a rational appetite. Reason is connected with the will, because it finds its principle in the natural inclination of the will to goodness and happiness. Reason and will are intertwined.

For Ockham, as well as for his teacher Scotus, the will itself moves to action and thus is the justification for free choice. It follows that the will may or may not adhere to the judgment of reason. The difference is on the side of reason that it is, so to speak, external to the decision of the will. The will is free in itself, and any influence could restrict its freedom.

The essential difference of the relationship between reason and will was also signed under the understanding of prudence. At the forefront of Thomas's thinking about prudence is practical reason, naturally equipped with knowledge of the first principles of action. These principles are the ends of moral virtues. The end of moral virtue is to maintain the good of a particular natural inclination in its proper proportion to the good of whole life (beatitude) and to what is the requirement of a particular situation. Prudence has the task of recognizing which act is appropriate in order to preserve the good of the individual inclination with regard to the overall goodness of a man, which is to be in accord with reason. Prudence for this appropriate recognition requires not only the knowledge of the ends, but also the support of the appetitive power, that is, the right inclination or moral virtue. Without moral virtue, prudence would not be perfect in its main act - the command to perform an act. A command is the last stage of an interior act, followed by a commanded (exterior) act. The cooperation of reason and will in the interior act thus leads to the exterior act, to the interaction with the world and to the growth in virtue.

For Ockham, natural inclinations fell out of consideration of prudence and virtue in general. If the will is free, it must not be guided by anything else, not by the request of lower potencies. In Thomas's conception, reason interprets these affections as a good to be preserved. But Ockham does not perceive inclinations and their role as essential and does not interpret them in this way. When virtue arises, free will is fundamental. Only such a free act can stand in the creation of a virtue in which the will applies the principles of practical reason. Reason therefore remained a subject of moral conduct. However, it is completely external to the proceedings. According to 
Ockham, the derivation of the principles of action does not yet imply anything moral; morality is exclusively connected with the act of will, only it is free.

The comparison of two views on the issue of virtue and especially rationality presented by Thomas Aquinas and William Ockham might seem unproblematic at first glance, as the authors referred to Aristotle. However, a more detailed insight into the issue of virtue showed us the fundamental differences and conclusions for both authors. Although the terms they both use have a common frame of reference, their content and interpretation change radically.

According to Thomas, human freedom "could never lead a human being to act contrary to his own interests. To choose against the principles of natural law would not constitute freedom, but rather foolishness" (Celano 2018). Ockham has a different opinion. What the will decides to do and knows as a principle of moral science, it compares with the principles of practical knowledge, which it acquires on the basis of specific experience and on the basis of judgment resulting from practical syllogism. In some cases, he does not have to adhere to the principles of natural law (which he calls the principles of moral science), because he is guided by a practical syllogism that is closer to action than moral science. For him, freedom is an act of will that adheres to what mediates its prudence this can sometimes differ from the principles of moral science.

Compared to Thomas Aquinas' thinking, there is a clear shift in Ockham's ethical theory especially by differentiating between interior and exterior acts and emphasizing the interior ones from the ethics of virtue to the incoming modern formalism and individualism and interpretation of virtue, which we can find in works of N. Machiavelli or T. Hobbes.

\section{REFERENCES}

Aquinas, Thomas. 2005. Disputed Questions on the Virtues. Atkins, E. M. (transl.), Atkins, E. M. Williams, Thomas (eds.). Cambridge.

Aquinas, Thomas. 2012. Summa Theologiae. Shapcote, Laurence (transl.), Mortensen, John Alarcón, Enrique (eds.). The Aquinas Institute, Lander, Wyoming. https://aquinas.cc.

Celano, Anthony. 2018. Medieval Theories of Practical Reason. In Zalta, Edward N. (ed.). The Stanford Encyclopedia of Philosophy (Winter 2018 Edition). https://plato.stanford.edu/ archives/win2018/entries/practical-reason-med/.

Chabada, Michal - Szapuová, Mariana. 2017. Ludská prirodzenost', rozum a emócie: Pohlad T. Akvinského a D. Huma. In Filozofia 72/9, 698-710.

Chabada, Michal. 2008. Zakotvenie etiky v prirodzenom zákone podla Jána Dunsa Scota. In Filozofia 63/3, 240-251.

Gallagher, David M. 2002. The Will and Its Acts (Ia IIae, qq. 6-17). In Pope, Stephen (ed.). The Ethics of Thomas Aquinas. Washington, 69-89.

Kemple, Brian. 2017. The Preeminent Necessity of Prudence. In Studia Gilsoniana 6/4, 549-572.

Machula, Tomáš. 2020. Morálka vycházející z rozumu. In Akvinský, Tomáš. O prozíravosti v Teologické sumě. Machula, Tomáš (transl.). Praha, 5-31.

Němec, Václav. 2008. Přirozený zákon podle Tomáše Akvinského. In Chvátal, Ladislav - Hušek, Vít (eds.). „Přirozenost“ ve filosofii minulosti a současnosti. Brno, 135-155.

Niederberger, Andreas. 2013. Prudentia und Scientia Moralis bei William von Ockham. In Fidora, Alexander et al. Phronésis - Prudentia - Klugheit. Das Wissen des Klugen in Mittelalter, Renaissance and Neuzeit. Brepols, 123-126.

Ockham, Guillelmi de. 1967. Scriptum in librum primum Sententiarum Ordinatio. Prologus et Distinctio prima. Gedeon Gál (ed.). New York. 
Ockham, Guillelmi de. 1984. Circa virtutes et vitia. In Etzkorn, J. Girard (ed.). Quaestiones variae. Opera Theologica vol. VIII. New York, 272-285.

Ockham, Viliam. 2016. Princíp biblie alebo o tom, či sú cnosti poprepájané. Nemec, Rastislav (transl.). In Ladislav Tkáčik (ed.). Studia Capuccinorum Boziniensia. Vol. II. Kraków, 103-172.

Osborne, Thomas. 2014. Human Action in Thomas Aquinas, John Duns Scotus \& William of Ockham. Washington.

Rhonheimer, Martin. 2011. The Perspective of Morality: Philosophical Foundations of Thomistic Virtue Ethics. Washington, DC.

Scotus, Duns Joannes. 1960. Lectura in librum Primum Sententiarum. Prologus et Liber Primus. Vol. XVI. Typis Polyglottis Vaticanis.

Scotus, Duns Ján. 2005. Teológia ako praktická veda. Chabada, Michal (transl.). Bratislava.

Thomae de Aquino. 1888. Summa Theologiae. In Busa, Roberto - Alarcón, Enrique (eds.). Corpus thomisticum. S. Thomae de Aquino Opera omnia. http://www.corpusthomisticum.org/iopera. html.

Thomae de Aquino. 1953. Quaestiones disputatae de virtutibus. In Busa, Roberto - Alarcón, Enrique (eds.). Corpus thomisticum. S. Thomae de Aquino Opera omnia. http://www. corpusthomisticum.org/iopera.html.

Vašek, Martin. 2013. Abelardova filozofická reflexia náboženského dialógu. In: Filozofia, 68/6, 481-492.

Volek, Peter. 2011. Vplyv aristotelizmu pri vysvetlovaní konania u Tomáša Akvinského. In Filozofia 66/1, 11-23.

Wood, Rega. 1997. Ockham on virtues. Indiana.

prof. PhDr. Rastislav Nemec, PhD.

University of Trnava

Faculty of Theology

Department of Christian Philosophy

Kostolná 1

81499 Bratislava

Slovakia

rastislav.nemec@truni.sk

ORCID ID: 0000-0002-6920-6395

WOS Researcher ID: AAC-4342-2021

SCOPUS Author ID: 26325736000

doc. Mgr. Andrea Blaščíková, PhD.

Constantine the Philosopher University in Nitra

Faculty of Arts

Department of Religious Studies

Hodžova 1

94974 Nitra

Slovakia

ablascikova@ukf.sk

ORCID ID: 0000-0001-6142-1464

WOS Researcher ID: AAG-7802-2020

SCOPUS Author ID: 56054484400 